\title{
ANALISIS KEMAMPUAN PEMAHAMAN MATEMATIS SISWA SMK KELAS XI PADA MATERI VEKTOR SELAMA PANDEMI COVID-19
}

\author{
Ena Suhena Praja ${ }^{1}$, Setiyani ${ }^{2}$, Lena Kurniasih ${ }^{3}$, Farhan Ferdiansyah ${ }^{4}$ \\ 1,2,4 Universitas Swadaya Gunung Jati, Jalan Perjuangan No.1, Cirebon, Indonesia \\ ${ }^{3}$ SMKN 1 Kota Cirebon, Jalan Perjuangan, Cirebon, Indonesia \\ Email: ${ }^{2}$ Setiyani@fkip-unswagati.ac.id
}

\begin{abstract}
This research is motivated by the importance of mathematical understanding of students in the pandemic. The implementation of learning is done online which is new for students. The purpose of this study is to analyze the mathematical comprehension skills of grade XI vocational students on vector material. The subject of the study was a grade XI student of one of the vocational schools in Cirebon which numbered two men. The research methodology used is qualitative type of case study by analyzing student answers and interview results. The instruments used are mathematical comprehension skills tests and interview sheets. Tests are used to provide a more in-depth explanation of a student's mathematical comprehension skills, while interviews are used to check answers to questions that have been done by students. The results are highly capable students have high mathematical comprehension skills with a percentage of $90 \%$, while moderately capable students have moderate mathematical comprehension skills with a percentage of $56,7 \%$. In other words, highly skilled students have high mathematical comprehension skills while moderately capable students have moderate mathematical comprehension skills.
\end{abstract}

Keywords: Mathematical understanding, online learning, vector

\section{ABSTRAK}

Penelitian ini dilatarbelakangi oleh pentingnya pemahaman matematis siswa di masa pandemi. Pelaksanaan pembelajaran dilakukan secara daring yang merupakan hal baru bagi siswa. Tujuan penelitian ini untuk menganalisis kemampuan pemahaman matematis siswa SMK kelas XI pada materi vektor. Subjek penelitian adalah siswa kelas XI salah satu SMK di kota Cirebon yang berjumlah dua orang laki-laki. Metodologi penelitian yang digunakan adalah kualitatif jenis studi kasus dengan menganalisis jawaban siswa dan hasil wawancara. Instrumen yang digunakan adalah tes kemampuan pemahaman matematis dan lembar wawancara. Tes digunakan untuk memberikan penjelasan yang lebih mendalam tentang kemampuan pemahaman matematis siswa, sedangkan wawancara digunakan untuk mengecek jawaban terhadap soal yang telah dikerjakan oleh siswa. Hasil yang diperoleh adalah siswa yang berkemampuan tinggi memiliki kemampuan pemahaman matematis tinggi dengan persentase $90 \%$, sedangkan siswa berkemampuan sedang memiliki kemampuan pemahaman matematis sedang dengan persentase $56,7 \%$. Dengan kata lain, siswa yang berkemampuan tinggi memiliki kemampuan pemahaman matematis tinggi sedangkan siswa berkemampuan sedang memiliki kemampuan pemahaman matematis sedang.

Kata kunci: Pemahaman matematis, pembelajaran daring, vektor

Dikirim: 29 November 2020; Diterima: 30 Januari 2021; Dipublikasikan: 30 Maret 2021

Cara sitasi: Praja, E. S., Setiyani., Kurniasih, L., \& Ferdiansyah, F. (2021). Analisis kemampuan pemahaman matematis siswa smk kelas xi pada materi vektor selama pandemi covid-19. Teorema: Teori dan Riset Matematika, 6(1), 12-24.

Doi: http://dx.doi.org/10.25157/teorema.v6i1.4539 


\section{PENDAHULUAN}

Saat ini dunia sedang mengalami wabah pandemi virus corona yaitu virus yang menyerang sistem pernapasan manusia. Coronavirus ditemukan dapat menyebabkan penyakit menular yang disebut Covid-19. Covid-19 dapat menyebar melalui percikan-pericikan cairan dari hidung ataupun dari mulut orang yang terserang virus yang kemudian tidak sengaja dihirup oleh orang yang tidak terkena virus tersebut (Dewi, 2020). Untuk itu dianjurkan untuk menjaga jarak ataupun social distancing di tengah masa pandemi ini untuk memutus rantai penyebaran. Selain itu, Covid-19 juga dapat bertahan pada benda-benda di sekitar kita. Oleh karena itu pemerintah memberi himbauan kepada masyarakat untuk tetap di rumah saja. Dampaknya, seluruh aktivitas masyarakat dari berbagai bidang dikurangi mulai dari bidang sosial, bidang ekonomi, bidang pariwisata sampai bidang pendidikan (Dewi, 2020). Pemerintah juga sudah mengeluarkan surat edaran pada tanggal 18 Maret 2020 yang mengatakan bahwa semua kegiatan yang melibatkan luar ruangan sementara ditunda termasuk bidang pendidikan. Kemendikbud RI pada tanggal 24 Maret 2020 mengeluarkan Surat Edaran Nomor 4 Tahun 2020 tentang Pelaksanaan Kebijakan Pendidikan dalam Masa Darurat Penyebaran Coronavirus Disease (Covid-19) yang menyebutkan bahwa proses belajar mengajar harus dilakukan dari rumah atau proses belajar mengajar melalui daring. Hal ini tentunya menjadi sesuatu yang baru yang dialami oleh guru maupun peserta didik.

Selama ini matematika merupakan salah satu pelajaran yang dianggap sulit oleh sebagian besar siswa (Marwiyah et al., 2020). Padahal matematika merupakan mata pelajaran penting yang berpengaruh dalam kehidupan manusia. Namun pentingnya matematika tidak dibarengi dengan minat yang baik dari siswa (Kadarisma et al., 2020). Matematika berperan dalam hampir segala aspek bahkan di masa teknologi dan digital sekarang ini. Guru harus bisa segera beradaptasi dengan keadaan sekarang yaitu pembelajaran secara daring. Karena diantara berbagai faktor yang dapat meningkatkan prestasi siswa adalah kemampuan siswa dalam menyusun rencana, menyusun strategi penyelesaian masalah, serta mengetahui alasan pemilihan strategi penyelesaian (Zakiah, 2020). Oleh karena itu, guru perlu bekerja ekstra memilih metode, model, dan strategi yang tepat untuk pembelajaran jarak jauh. Dalam pembelajaran secara tatap muka, tidak jarang matematika dinilai sulit oleh siswa. Padahal itu semua hanya anggapan yang belum pasti kebenarannya (Gazali, 2016). Pemikiran bahwa matematika adalah pelajaran yang sulit tersebut bisa menjadi faktor menurunnya pemahaman matematis siswa. Selain itu, rata-rata siswa memiliki kebiasaan belajar yang kurang baik yaitu dengan cara menghafal tanpa pemahaman mereka sendiri (Sari, 2019). Turmudi (Fuadi, 2016) mengemukakan bahwa pembelajaran matematika selama ini disampaikan kepada siswa secara informatif, artinya siswa hanya memperoleh informasi dari guru saja sehinga derajat kemelekatannya juga dapat dikatakan rendah. Dengan pembelajaran seperti ini, siswa kurang dilibatkan untuk memahami konsep-konsep matematika yang dipelajarinya. Pemahaman akan membantu siswa mengembangkan bagaimana berpikir dan bagaimana membuat keputusan.

Menurut Permendiknas nomor 22 tahun 2006 tentang Standar Isi, tujuan pembelajaran matematika di sekolah menengah atas adalah agar peserta didik memiliki kemampuan memahami konsep matematika, menjelaskan keterkaitan antar konsep, dan mengaplikasikan konsep atau algoritma secara luwes, akurat, efisien, dan tepat dalam pemecahan masalah. Hill \& Ball (Nursaadah \& Amelia, 2018) memahami konsep dalam belajar matematika adalah salah satu hal yang sangat penting karena dengan pemahaman konsep tersebut siswa menjadi tahu mengapa dan bagaimana logika matematika bekerja dalam kehidupan. Namun pada kenyataannya siswa tidak diberikan kesempatan untuk memahami lebih dalam mengenai materi yang diberikan. Siswa hanya fokus untuk mendapatkan jawaban kemudian menyerahkan ke guru untuk dikoreksi apakah jawaban tersebut benar atau salah. Maka dari itu dalam pembelajaran matematika kebanyakan siswa mengandalkan hafalan dibandingkan pemahaman terhadap soal-soal matematika (Sariningsih, 2014). Hafalan dalam pembelajaran matematika berimbas pada ketidaktahuan makna yang terkandung dalam konsep tersebut sehingga pada saat mengerjakan soal sering melakukan kesalahan dan tidak menemukan solusi permasalahannya (Nursaadah \& Amelia, 2018). 
Pada masa pandemi, siswa belajar mandiri dengan melihat video pembelajaran yang dibuat oleh guru dan dikirimkan melalui google classroom. Berdasarkan evaluasi, mayoritas siswa tidak melihat video secara utuh dan langsung menjawab soal-soal dari google form. Oleh karena itu perlu analisis mendalam terkait kemampuan pemahaman matematis yang dimiliki siswa selama melaksanakan pembelajaran jarak jauh.

Beberapa penelitian terkait analisis kemampuan pemahaman matematis telah banyak dilakukan. Penelitian yang dilakukan Syarifah (2017) berjudul Analisis Kemampuan Pemahaman Matematis pada Mata Kuliah Pembelajaran Matematika SMA II, dengan metode pengumpulan data yang digunakan adalah tes kemampuan pemahaman matematis, observasi, wawancara dan dokumentasi. Hasil penelitian menunjukkan bahwa kemampuan pemahaman matematis mahasiswa masih dibawah nilai yang ditetapkan yaitu 70 . Selanjutnya penelitian yang dilakukan oleh Nursaadah \& Amelia (2018) berjudul Analisis Kemampuan Pemahaman Matematis Siswa SMP pada Materi Segitiga dan Segiempat, dengan teknik pengumpulan data yang digunakan adalah tes kemampuan pemahaman matematis dan melakukan wawancara. Hasil penelitian menunjukkan bahwa siswa masih kesulitan untuk mengerjakan 4 dari 5 soal, sehingga indikator tidak tercapai dan dikategorikan berkemampuan pemahaman matematis rendah. Penelitian lain yang dilakukan oleh Mulyani et al, (2018) berjudul Analisis Kemampuan Pemahaman Matematis Siswa SMP pada Materi Bentuk Aljabar. Instrumen yang digunakan pada penelitian ini adalah tes kemampuan pemahaman matematis dan angket. Hasil penelitian menunjukkan bahwa kemampuan pemahaman matematis siswa masih rendah yang ditunjukkan oleh hasil tes. Adapun keterbaruan dalam penelitian ini adalah menganalisis kemampuan pemahaman matematis siswa SMK kelas XI pada materi vektor selama pandemi Covid-19. Melalui kajian mendalam tentang kemampuan pemahaman matematis siswa pada topik vektor selama masa pandemi dapat diperoleh gambaran kesulitan dan kesalahan apa yang dialami siswa. Selanjutnya, guru dapat merancang pembelajaran yang tepat untuk meminimalisir kesalahan yang dilakukan oleh siswa.

Salah satu pembahasan dalam mata pelajaran matematika adalah materi Vektor. Vektor merupakan salah satu materi matematika yang dipandang cukup sulit. Berdasarkan hasil penelitian di salah satu SMA Negeri di kota Palu, diperoleh hasil bahwa kemampuan pemahaman matematis siswa kelas XII masih tergolong rendah (Sari et al., 2017). Oleh karena itu, peneliti tertarik untuk meneliti pemahaman matematis siswa pada mata pelajaran vektor dengan subjek siswa SMK. Berdasarkan pembahasan sebelumnya, terdapat permasalahan pemahaman matematis pada materi vektor. Peneliti bermaksud untuk memperoleh gambaran kemampuan pemahaman matematis siswa SMK kelas XI pada materi vektor selama masa pandemi Covid-19.

\section{METODE PENELITIAN}

Penelitian ini menggunakan metodologi kualitatif dengan desain studi kasus. Penelitian ini menggambarkan analisis kemampuan pemahaman matematis siswa SMK kelas XI pada materi vektor selama masa pandemi Covid-19 yang berpedoman pada penskoran dan indikator kemampuan pemahaman matematis. Penelitian ini dilakukan pada tanggal 7 September 2020 sampai 2 Oktober 2020. Subjek penelitian ini adalah dua orang siswa kelas XI di salah satu SMK di kota Cirebon. Subjek penelitian ini adalah dua siswa kelas XI dengan kemampuan tinggi dan sedang yang berpedoman pada nilai tugas. Adapun kriteria pengambilan subjek penelitian berdasarkan nilai yang sudah diranking, serta dua subjek penelitian tersebut sudah cukup memberikan informasi dalam penelitian ini. Keterbatasan peneliti dalam melakukan wawancara kepada siswa juga menjadi faktor dalam pengambilan kriteria subjek penelitian.

Teknik pengambilan data ini menggunakan tujuh butir soal uraian pemahaman matematis siswa. Indikator pemahaman matematis menurut NCTM (Hendriana et al, 2017) yaitu: (1) mendefinisikan konsep secara verbal dan tulisan; (2) mengidentifikasi dan membuat contoh dan bukan contoh; (3) menggunakan model, diagram dan simbol-simbol untuk merepresentasikan suatu konsep; (4) mengubah suatu bentuk representasi ke bentuk representasi lainnya; (5) mengenal berbagai makna dan interpretasi konsep; dan (6) mengidentifikasi sifat-sifat suatu konsep dan 
mengenal syarat yang menentukan suatu konsep. Teknik analisis yang dilakukan dengan tiga tahap, yaitu: (1) mereduksi data, dalam hal ini peneliti menganalisis data hasil tes; (2) mendeskripsikan hasil analisis data dan memberikan kesimpulan sebagai jawaban dari rumusan masalah; dan (3) menyusun laporan penelitian. Prosedur dalam penelitian ini terdiri dari tiga tahap, yaitu: (1) tahap persiapan; (2) tahap pelaksanaan; dan (3) tahap akhir. Langkah-langkah tahap persiapan yang dilakukan, yaitu: (1) melakukan pra riset siswa SMK; (2) menyiapkan soal penelitian untuk tes soal kemampuan pemahaman matematis; dan (3) menyusun pedoman wawancara. Pada tahap pelaksanaan, diantaranya: (1) memberikan tes kepada siswa kelas XI SMK; (2) menganalisis jawaban subjek penelitian; dan (3) mewawancarai siswa dari apa yang dikerjakan. Pada tahap akhir adalah menganalisis data penskoran dengan dua orang subjek siswa SMK terhadap kemampuan pemahaman matematis dengan menggunakan rubrik penilaian seperti pada Tabel 1.

Tabel 1. Kriteria penilaian kemampuan pemahaman matematis

\begin{tabular}{cc}
\hline Indikator & Skor maksimal \\
\hline 1 & 5 \\
2 & 10 \\
3 & 20 \\
4 & 10 \\
5 & 15 \\
6 & 10 \\
Jumlah & 70 \\
\hline
\end{tabular}

Selanjutnya untuk menghitung persentasenya menggunakan rumus berikut:

$$
\text { Persentase kemampuan siswa }=\frac{\text { skor siswa }}{\text { skor maksimal }} \times 100 \%
$$

Data hasil kemampuan pemahaman matematis siswa akan dikategorikan menggunakan kategori menurut Suprihatin (2018) disajikan pada Tabel 2.

Tabel 2. Kategori kemampuan pemahaman matematis siswa

\begin{tabular}{cc}
\hline Kategori & Pencapaian pemahaman matematis siswa \\
\hline Tinggi & $>70 \%$ \\
Sedang & $55 \% \geq 70 \%$ \\
Rendah & $\leq 55 \%$ \\
\hline
\end{tabular}

\section{HASIL DAN PEMBAHASAN}

Penelitian yang dilakukan bertujuan untuk mengetahui gambaran kemampuan pemahaman matematis siswa SMK pada materi Vektor. Penelitian ini dilakukan di salah satu SMK di kota Cirebon dan subjek penelitiannya adalah kelas XI TKR. Untuk menjawab pertanyaan peneliti, maka dilakukan tes kemampuan pemahaman matematis siswa sesuai dengan indikator yang dikemukakan oleh NCTM (1989). Deskripsi skor kemampuan pemahaman matematis siswa dalam setiap indikator soal disajikan pada Tabel 3.

Tabel 3. Deskripsi skor kemampuan pemahaman matematis siswa setiap indikator

\begin{tabular}{ccc}
\hline Indikator & \multicolumn{3}{c}{ Skor siswa } \\
\hline 1 & Siswa A & Siswa B \\
2 & 5 & 5 \\
3 & 10 & 0 \\
4 & 13 & 6 \\
5 & 10 & 10 \\
6 & 15 & 10 \\
Jumlah & 10 & 10 \\
Persentase & 63 & 41 \\
\hline
\end{tabular}

Berdasarkan Tabel 3, perolehan persentase yang tinggi baik pada siswa A maupun siswa B yaitu pada indikator 1 (mendefinisikan konsep secara tulisan), indikator 4 (mengubah suatu bentuk representasi ke bentuk representasi lainnya, dan indikator 6 (mengidentifikasi sifat-sifat suatu 
konsep). Hasil jawaban siswa $A$ dan siswa $B$ terhadap indikator yang pertama dari kemampuan pemahaman matematis disajikan pada Gambar 1 dan Gambar 2.

Indikator 1 : Medefinisikan konsep secara verbal dan tulisan

Soal : : Tuliskan definisi vektor yang kalian ketahui.

Jawaban siswa:

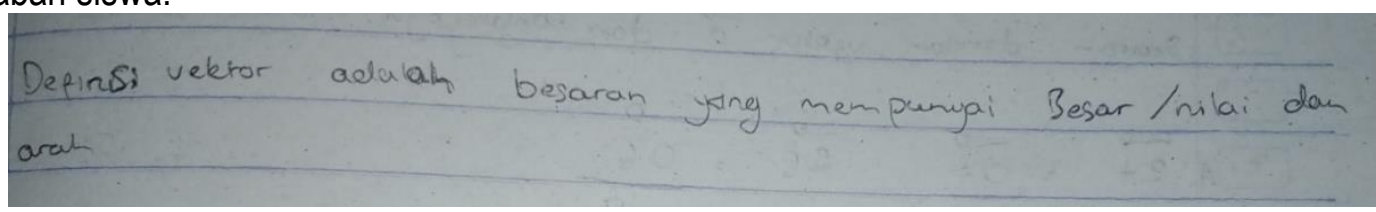

Gambar 1. Jawaban siswa A untuk indikator 1

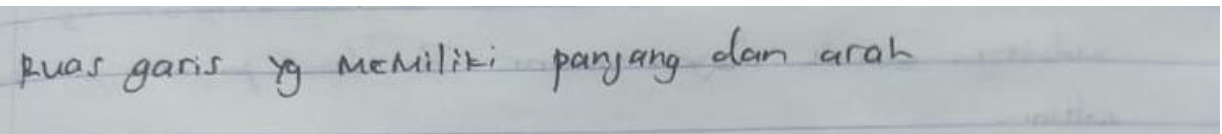

Gambar 2. Jawaban siswa B untuk indikator 1

Cuplikan wawancara dengan siswa A:

$P$ : Apakah Anda yakin jika jawaban Anda sudah benar?

A : Yakin Pak

$P$ : Apakah Anda memahami kalimat yang Anda tulis?

A : Kurang paham Pak

$P$ : Kenapa kurang paham?

$A$ : Ya bingung aja Pak maksud dari besaran yang memiliki besar itu gimana?

Cuplikan wawancara dengan siswa $B$ :

$P$ : Apakah Anda yakin jawaban Anda sudah benar?

$B$ : Kurang tau Pak, tapi kayaknya jawabannya itu

$P$ : Apakah Anda memahami maksud kalimat yang Anda tulis?

$B$ : Ga paham Pak soalnya dapat dari google kalo ga salah

Berdasarkan Gambar 1 dan Gambar 2, baik siswa A maupun siswa B mampu menjawab definisi vektor dengan baik yaitu suatu besaran yang memiliki nilai dan arah. Tetapi pada saat wawancara, ternyata baik siswa A maupun siswa B kurang memahami maksud kalimat yang ditulisnya. Berdasarkan hasil wawancara, siswa belum memahami betul definisi dari vektor. Indikator mendefinisikan konsep secara tulisan memiliki persentase 100\% yaitu termasuk ke dalam kategori tinggi. Sanjaya (Murtianto et al., 2019) mengemukakan bahwa seseorang dikatakan memahami konsep apabila mampu menerangkan konsep secara verbal mengenai apa yang sudah dicapainya. Namun dari hasil wawancara, siswa belum memahami sepenuhnya apa itu definisi vektor sehingga baik siswa A maupun siswa B belum mencapai indikator mendefinisikan konsep secara verbal.

Indikator 2 : Mengidentifikasi contoh dan bukan bukan contoh

Soal : Kelompokkan vektor-vektor dibawah ini ke dalam vektor dimensi dua atau vektor dimensi tiga.
a. $\vec{a}=\langle 2,1\rangle$
b. $\quad \vec{v}=-\vec{\imath}-2 \vec{\jmath}+3 \vec{k}$
c. $\vec{c}=\langle 2,1,-2\rangle$
d. $\vec{f}=-\vec{\imath}-2 \vec{\jmath}$
e. $\vec{d}=\langle 2,0,-2\rangle$
f. $\quad \vec{g}=0 \vec{\imath}-2 \vec{\jmath}$
g. $\vec{h}=\langle 2,11\rangle$
h. $\quad \vec{p}=-\vec{\imath}-2 \vec{\jmath}+0 \vec{k}$ 
Hasil jawaban siswa A dan siswa B terhadap indikator yang kedua dari kemampuan pemahaman matematis disajikan pada Gambar 3 dan Gambar 4.

Jawaban siswa:

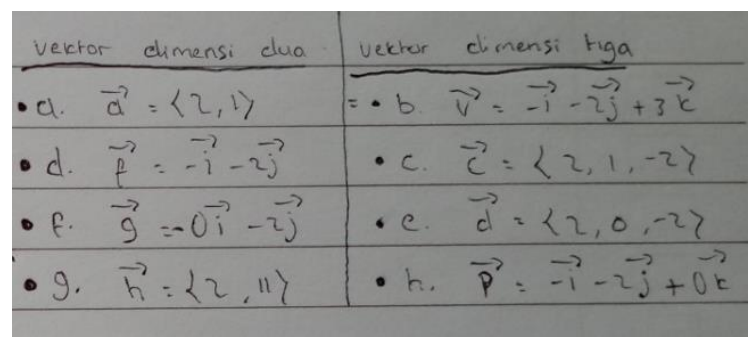

Gambar 3. Jawaban siswa A untuk indikator 2

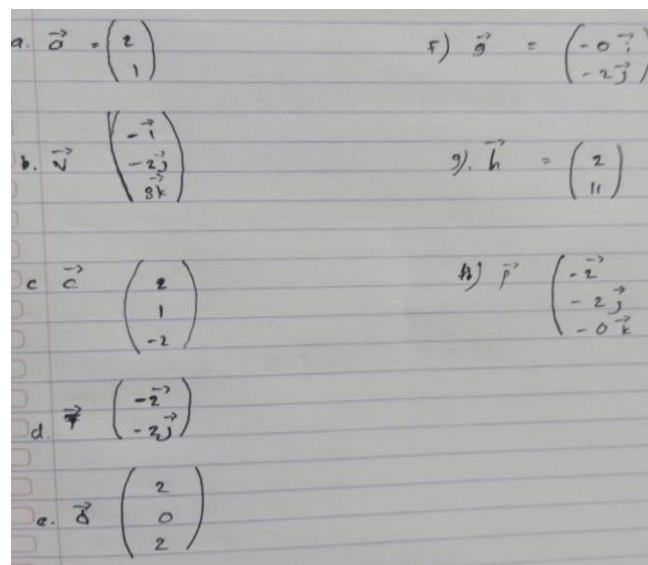

Gambar 4. Jawaban siswa B untuk indikator 2

Cuplikan wawancara dengan siswa A:

$P$ : Apakah Anda yakin dengan jawaban Anda?

A : Yakin Pak

$P$ : Apa yang Anda pahami dari soal yang saya berikan?

$A$ : Yang saya pahami dari soal vektor tersebut, yaitu vektor dimensi 2 itu vektor basis yang hanya $i$ dan $j$ saja. Sedangkan dimensi 3, vektor basis i, $j$ dan $k$ atau ada 3 golongan.

Cuplikan wawancara dengan siswa $\mathrm{B}$ :

$P$ : Apakah Anda yakin bahwa jawaban Anda sudah benar?

$B$ : Kurang yakin Pak, itu maksudnya vektor dimensi 2 kumpul di satuin terus vektor dimensi 3 dikumpulin gitu tah Pak?

$P$ : Sepemahaman Anda bagaimana?

$B$ : (Siswa mengirimkan jawaban lagi ditampilan pada Gambar 5)

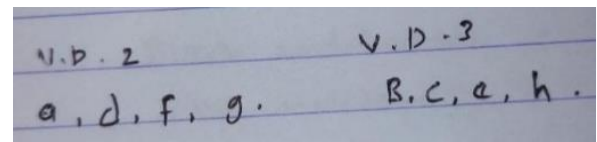

Gambar 5. Jawaban siswa B untuk indikator 2

$P$ : Apakah Anda yakin dengan jawaban Anda yang barusan dikirim?

$B$ : Yakin Pak

$P$ : Bisa tolong jelaskan mengapa Anda menjawab demikian?

$B$ : Karena kalau yang vektor dimensi 2 itu terdapat 2 angka misal $(2,3)$ / i dan j. Kalau vektor dimensi 3 terdapat 3 angka misal $(3,5,7) / i$, j, dan $k$.

Berdasarkan Gambar 3 dan Gambar 4, diketahui bahwa siswa A mampu menjawab pertanyaan dengan benar dan mampu memahami dengan baik pertanyaan yang peneliti berikan. Lain halnya dengan siswa $B$, pada awalnya siswa $B$ kurang memahami soal yang peneliti berikan. Namun, pada saat kegiatan wawancara, siswa B menyadari kesalahan jawabannya dan kemudian 
mengirimkan kembali jawaban yang ia yakini benar. Dapat disimpulkan bahwa untuk soal indikator 2 , siswa B kurang memahami dengan baik terhadap soal yang peneliti berikan. Kesulitan yang dialami salah satunya adalah siswa kurang dapat memahami soal yang diberikan secara daring tetapi siswa tidak mau bertanya. Siswa tidak menerima konsep secara langsung antara siswa dan guru sehingga menyebabkan siswa hanya bisa pasrah karena tidak paham terhadap soal yang diberikan melalui daring (Utami \& Cahyono, 2020).

Indikator 3 : Merepresentasikan suatu konsep dalam bentuk model, diagram, dan simbol

Soal : Gambarlah vektor-vektor berikut pada bidang koordinat Cartesius.
a. $\vec{a}=\langle 0,3\rangle$
b. $\vec{s}=\langle 5,0\rangle$
c. $\vec{d}=\langle-4,5\rangle$
d. $\vec{f}=\langle 0,5,0\rangle$

Hasil jawaban siswa A dan siswa B terhadap indikator yang ketiga dari kemampuan pemahaman matematis disajikan pada Gambar 6 dan Gambar 7. Jawaban Siswa:

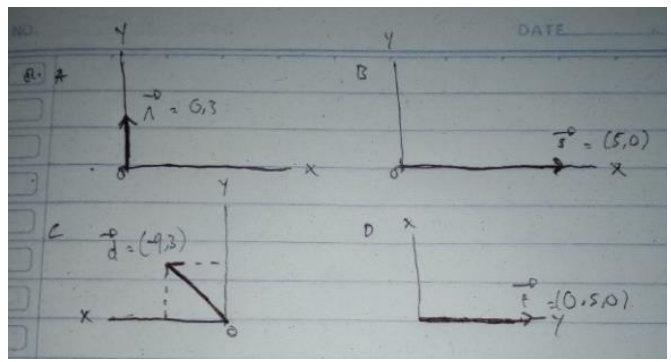

Gambar 6. Jawaban siswa A untuk indikator 3

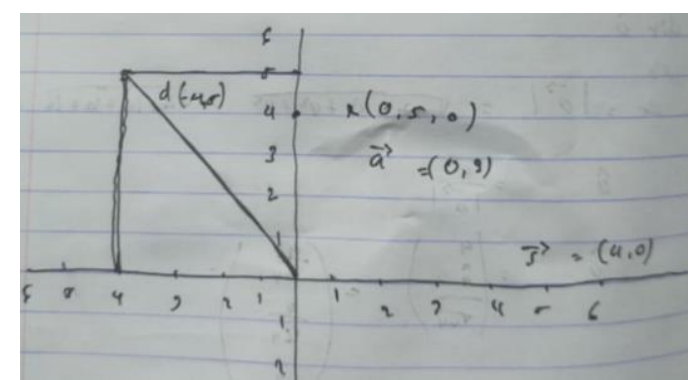

Gambar 7. Jawaban siswa B untuk indikator 3

Cuplikan wawancara dengan siswa A:

$P$ : Apakah Anda yakin jawaban Anda sudah benar?

A : Yakin Pak

$P$ : Apakah Anda merasa ada yang keliru dengan jawaban Anda?

A : Tidak Pak

$P$ : Tolong jelaskan jawaban yang Anda tulis!

A : Membuat titik koordinat dari vektor-vektor yang tertera

$P:$ Bagaimana dengan jawaban bagian d?

A : Kan disitu ada $3(0,5,0)$ tapi di titik koordinat kan hanya ada $x$ dan y Pak. Jadi masih bingung aja pak. Kalo ada soal yang disuruh bikin titik koordinat dari vektor dimensi tiga kaya gitu

Cuplikan wawancara dengan siswa B:

$P$ : Apakah Anda yakin dengan jawaban Anda?

$B$ : Kurang yakin Pak

$P$ : Mengapa?

$B$ : Karena angka yang ke bawah sama ke kiri itu negatif, itu positif semua. 
$P$ : Apakah adalagi yang tidak Anda yakini?

$B$ : Jawabannya juga mungkin salah Pak

$P$ : Bagian mana?

$B$ : Semua mungkin Pak

$P$ : Kenapa Anda tidak yakin dengan jawaban Anda?

$B$ : Banyak yang ngasal mungkin karena terburu-buru

Berdasarkan Gambar 6 dan Gambar 7, siswa masih kurang mampu memahami cara membuat grafik kartesius yang baik. Siswa A tidak menuliskan garis bilangan yang terdapat pada grafik kartesius. Sedangkan siswa B menuliskannya hanya saja terdapat kekeliruan dalam menuliskan tandanya, namun siswa B menyadari hal tersebut pada saat ditelusuri melalui wawancara. Siswa $B$ juga kurang teliti dengan tidak menuliskan nama garis $X$ dan $Y$. Untuk jawabannya, siswa A pada awalnya yakin dengan jawaban yang ditulis, tetapi siswa A tidak menyadari kekeliruan jawaban yang telah dikerjakannya. Namun, setelah diberi rangsangan pertanyaan, siswa A kemudian menyadari bahwa ada yang keliru terhadap jawaban yang telah ditulisnya. Dapat disimpulkan bahwa siswa A masih kurang memahami bagaimana cara membuat grafik kartesius tiga dimensi. Begitu pula dengan siswa B, siswa B menjadikan jawaban untuk seluruh sub nomor ke dalam satu grafik kartesius tanpa menyadari bahwa pada soal tersebut terdapat vektor dimensi tiga yang harus digambar pada grafik kartesius dimensi tiga. Pada sesi wawancara, siswa B juga kurang meyakini jawaban yang dia tulis karena merasa kurang bersungguh-sungguh dalam mengerjakan soal tersebut. Kesulitan dalam menggambar grafik dipengaruhi oleh pemahaman siswa terhadap materi yang diberikan (Susilo et al, 2019).

Indikator 4 : Mengubah suatu bentuk representasi ke dalam bentuk representasi lainnya

Soal : : Ubahlah vektor-vektor dibawah ini ke dalam vektor basis
a. $(-2,-3)$
b. $(-3,-2,-1)$
c. $\left(\begin{array}{c}9 \\ 10 \\ 13\end{array}\right)$
d. $\left(\begin{array}{c}2 \\ -3\end{array}\right)$

Hasil jawaban siswa A dan siswa B terhadap indikator yang keempat dari kemampuan pemahaman matematis disajikan pada Gambar 8 dan Gambar 9.
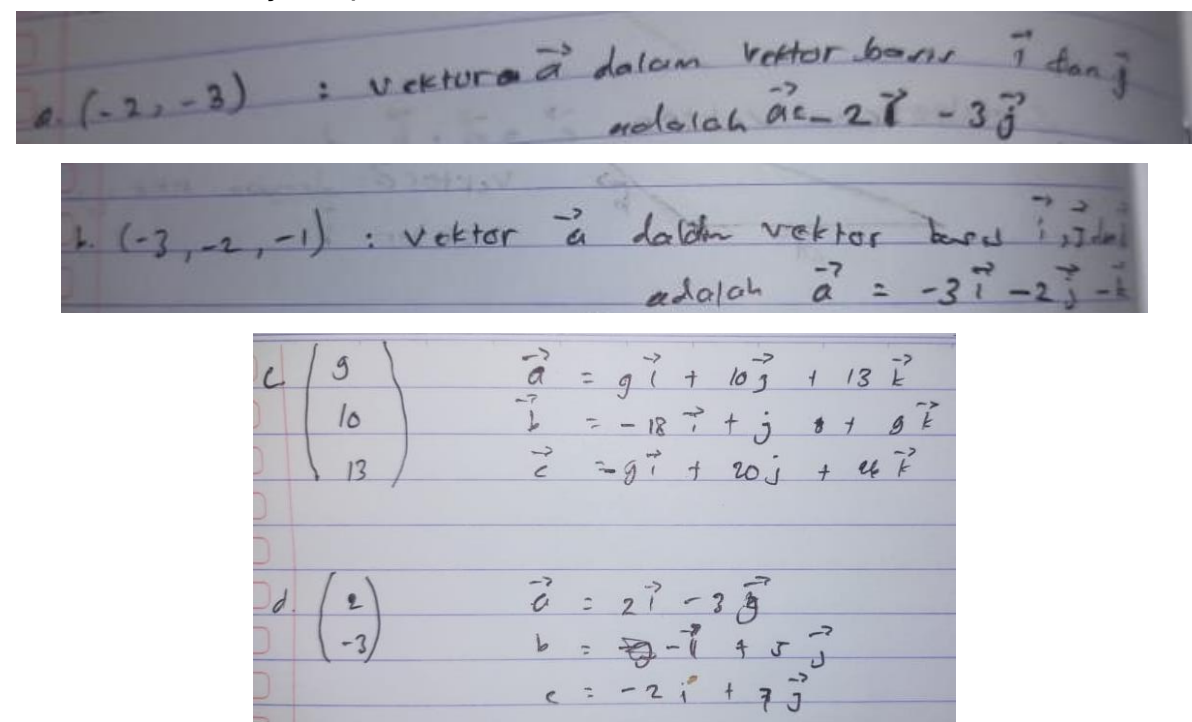

Gambar 8. Jawaban siswa A untuk indikator 4 


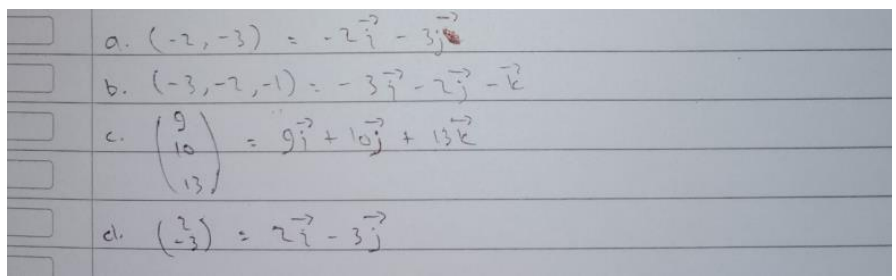

Gambar 9. Jawaban siswa B untuk indikator 4

Cuplikan wawancara dengan siswa $\mathrm{A}$ :

$P$ : Apakah Anda yakin dengan jawaban Anda?

$A$ : Yakin Pak

$P$ : Bisa tolong jelaskan maksud dari soal yang saya berikan?

A : Mengubah vektor baris dan vektor kolom ke dalam vektor basis $i, j$, dan $k$ sesuai dengan dimensinya.

Cuplikan wawancara dengan siswa $\mathrm{B}$ :

$P$ : Apakah Anda yakin dengan jawaban Anda?

$B$ : Ga yakin Pak, alasannya karena kurang paham Pak caranya belum ngerti

$P$ : Bagian mana yang belum dipahami?

$B$ : Semuanya Pak

Berdasarkan jawaban siswa A dan B pada Gambar 8 dan Gambar 9, siswa A mampu memahami soal yang peneliti berikan dengan benar, siswa $A$ juga mampu menjelaskan maksud dari soal yang telah peniliti berikan. Lain halnya dengan siswa $B$, siswa $B$ mampu menjawab dengan benar soal yang peneliti berikan. Namun berdasarkan hasil wawancara, siswa B nampak belum begitu memahami mengenai jawaban yang ia tulis. Siswa $B$ hanya mengikuti langkah-langkahnya melalui contoh soal tanpa memahami maksud dari soal tersebut. Kesimpulannya, untuk tes tertulis memang siswa $A$ dan siswa $B$ mampu menjawab dengan benar, tetapi untuk pemahamannya, hanya siswa A yang mampu memahami maksud soal yang peneliti berikan. Menurut McCoy et al. (Hutagaol, 2013) cara terbaik untuk membantu siswa dalam memahami matematika adalah adalah dengan cara mendorong mereka untuk membuat suatu representasi.

Indikator 5: Mengenal berbagai makna dari interpretasi konsep

Soal:

Diketahui:

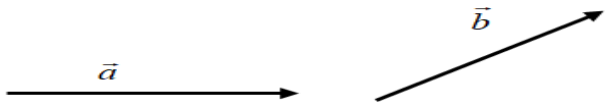

Gambarkan vektor $\vec{c}=\vec{a}+\vec{b}$ dengan metode segitiga.

Diketahui:

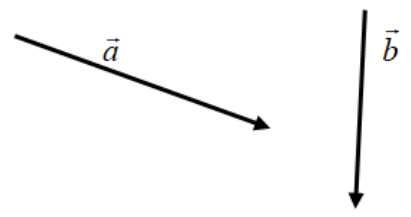

Gambarkan vektor $\vec{c}=\vec{a}+(-\vec{b})$ dengan metode segitiga.

Hasil jawaban siswa $A$ dan siswa $B$ terhadap indikator yang kelima dari kemampuan pemahaman matematis disajikan pada Gambar 10 dan Gambar 11. Jawaban Siswa:
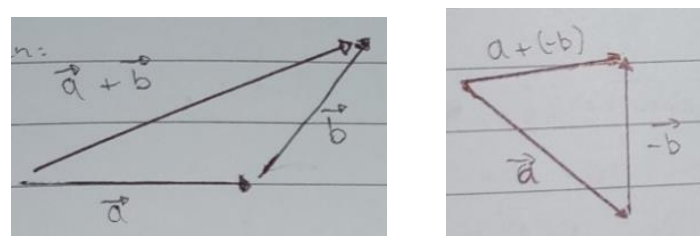

Gambar 10. Jawaban siswa A untuk indikator 5 

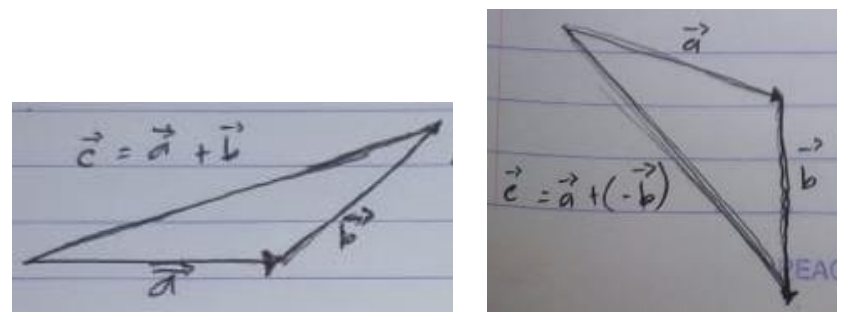

Gambar 11. Jawaban siswa B untuk indikator 5

Cuplikan wawancara dengan siswa A:

$P$ : Apakah Anda yakin dengan jawaban Anda?

A : Yakin Pak

$P$ : Bisa tolong jelaskan mengapa Anda menjawab seperti itu?

$A$ : Menggambar vektor dengan metode segitiga hanya menggabungkan titik pangkal vektor a menuju titik ujung vektor $b$

Cuplikan wawancara dengan siswa $\mathrm{B}$ :

$P$ : Apakah Anda yakin jawaban Anda sudah benar?

$B$ : Yakin Pak

$P$ : Bisa tolong jelaskan mengapa Anda menjawab seperti itu?

$B$ : Karena kan itunya memakai rumus segitiga Pak, nah yaudah setiap ujungnya ditempelin tapi bukan dengan panah

Interpretasi terjadi ketika siswa mampu mengubah satu bentuk representasi ke bentuk representasi lainnya (Arnidha, 2017). Berdasarkan Gambar 10 dan Gambar 11, terlihat bahwa siswa A sudah mampu memahami dengan benar mengenai persoalan yang peneliti berikan. Hasil wawancara juga menunjukkan bahwa siswa A mampu menjelaskannya dengan tepat. Sedangkan untuk jawaban siswa B masih terdapat kekeliruan untuk soal kedua. Siswa B masih belum memahami betul konsep dari penjumlahan dan pengurangan vektor sehingga mengakibatkan kesalahan dalam menggambar.

Indikator 6 : Mengidentifikasi sifat-sifat suatu konsep

Soal : (1) Menggunakan huruf kecil yang dibubuhi tanda titik dua di atasnya

(2) Menggunakan huruf kecil yang dibubuhi tanda kutip

(3) Menggunakan huruf kecil yang dibubuhi tanda panah di atasnya

(4) Menggunakan huruf kecil yang diberi topi

Dari keempat pernyataan tersebut, mana yang termasuk cara menuliskan vektor

Hasil jawaban siswa A dan siswa B terhadap indikator yang keenam dari kemampuan pemahaman matematis disajikan pada Gambar 12 dan Gambar 13.

Jawaban siswa:

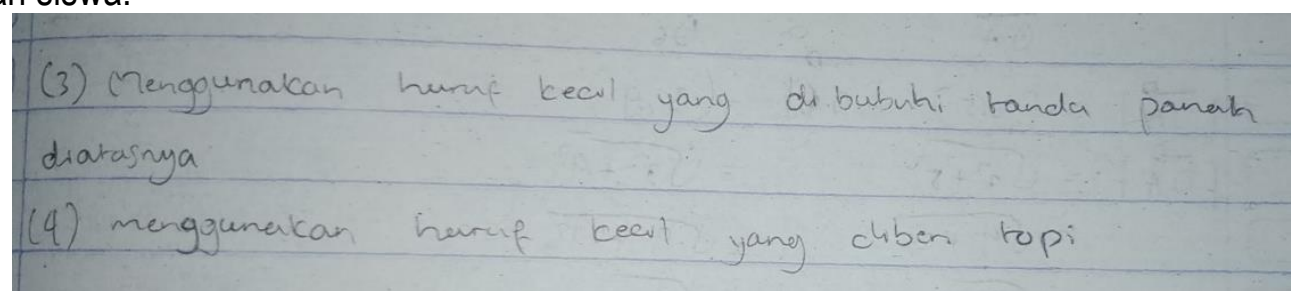

Gambar 12. Jawaban siswa A untuk indikator 6

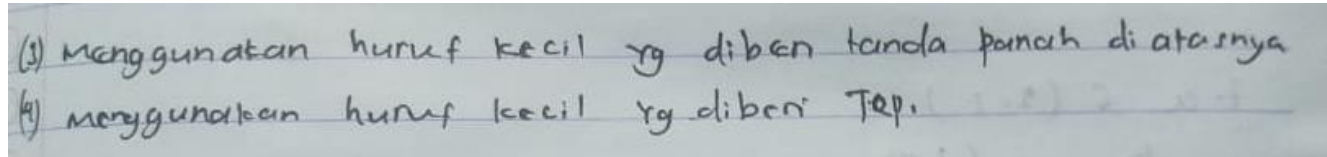

Gambar 13. Jawaban siswa B untuk indikator 6 
Cuplikan wawancara dengan siswa A:

$P$ : Apakah Anda yakin jawaban Anda sudah benar?

A : Yakin Pak

$P$ : Bisa tolong jelaskan mengapa Anda menjawab seperti itu?

A : Karena vektor biasanya ditandai dengan huruf kecil yang dibubuhi tanda panah di atasnya dan juga menggunakan huruf kecil yang diberi topi di atasnya.

Cuplikan wawancara dengan siswa $\mathrm{B}$ :

$P$ : Apakah Anda yakin jawaban Anda sudah benar?

$B$ : Yakin Pak bener

$P$ : Bisa tolong jelaskan mengapa Anda menjawab seperti itu?

$B$ : Alasanya karna saya sering melihat vektor yang ditulis seperti itu. Tapi yang saya tulis nomor 3 dan 4 saya yakinnya jawabannya hanya nomor 3 saja Pak

$P$ : Berarti Anda tidak yakin dengan jawaban yang Anda tulis?

$B$ : lya Pak

$P$ : Kenapa Anda tidak yakin dengan jawaban Anda?

$B$ : Karena menurut saya jawaban yang benar adalah yang nomor 3 nya saja

$P$ : Mengapa Anda yakin seperti itu?

$B$ : Karena mungkin jawaban yang benarnya seperti itu Pak.

Siswa harus mampu mengidentifikasi sifat-sifat suatu konsep dan mengenal syarat yang menentukan konsep ke dalam soal yang ditanyakan oleh peneliti (Arnidha, 2017). Berdasarkan Gambar 12 dan Gambar 13, terlihat siswa A maupun siswa B dapat menjawab dengan tepat terhadap pertanyaan yang diberikan oleh peneliti. Pada saat wawancara, siswa A mampu menjelaskan jawaban dengan benar atas jawaban yang ia tulis. Sementara untuk siswa B tidak yakin dengan jawaban yang ia tulis. Siswa B meyakini bahwa jawaban yang sebenarnya hanya poin 3 karena siswa B lebih sering melihat vektor ditulis dengan demikian. Siswa B kurang mampu memahami bahwa penulisan vektor sebenarnya terdapat tiga cara.

Dari keenam indikator yang disebutkan, secara tes tulis, siswa A dan siswa B dapat mencapai indikator 1,4 dan 6 . Sedangkan untuk indikator 2,3 dan 5 belum tercapai sempurna. Namun dari hasil wawancara, baik siswa A maupun siswa B masih kurang memahami terhadap soal-soal yang indikatornya telah dicapai oleh kedua siswa tersebut secara tes tertulis. Siswa masih bingung dalam menerjemahkan dan memahami soal yang diberikan. Siswa juga terkadang tidak memahami jawaban yang mereka tulis sendiri dan hanya mengikuti langkah demi langkahnya dari contoh soal.

\section{KESIMPULAN}

Berdasarkan hasil penelitian yang dilakukan di salah satu SMK di Kota Cirebon kelas XI, dapat ditarik kesimpulan bahwa kemampuan matematis siswa yang berkemampuan tinggi tergolong tinggi walaupun pembelajaran dilakukan pada saat pandemi Covid-19 ini melalui daring, sedangkan siswa yang berkemampuan sedang memiliki kemampuan matematis kategori sedang. Terdapat faktor-faktor yang membuat siswa masih kurang memahami persoalan matematika pada saat pembelajaran selama pandemi Covid-19 ini diantaranya adalah: (1) kurangnya minat belajar siswa dalam mata pelajaran matematika dikarenakan anak SMK lebih fokus terhadap mata pelajaran jurusannya; (2) matematika hanya dianggap sebagai mata pelajaran dengan banyak rumus sehingga siswa lebih banyak menggunakan hafalan dalam pembelajaran matematika dibandingkan dengan memahami dengan betul mata pelajaran matematika; (3) siswa hanya mengejar nilai dan hanya berusaha menjawab dengan benar tanpa memahami konsepnya; dan (4) dikarenakan kegiatan pembelajaran dilakukan melalui daring, maka bukan tidak mungkin bagi siswa untuk mencari jalan pintas untuk menemukan jawaban terhadap persoalan-persoalan yang diberikan oleh guru melalui media internet. 


\section{REKOMENDASI}

Rekomendasi untuk peneliti selanjutnya adalah mencoba untuk mengaitkan kemampuan pemahaman matematis siswa dengan motivasi belajar menggunakan instrumen angket untuk mengetahui bagaimana gambaran pemahaman matematis dan motivasi belajar siswa pada saat pandemi Covid-19.

\section{UCAPAN TERIMAKASIH}

Penulis mengucapkan terima kasih kepada Universitas Swadaya Gunung Jati dan SMKN 1 Kota Cirebon khususnya XI-TKRO yang telah memfasilitasi kami untuk melakukan penelitian ini.

\section{DAFTAR PUSTAKA}

Arnidha, Y. (2017). Analisis pemahaman konsep matematika siswa sekolah dasar dalam penyelesaian bangun datar. JPGMI: Jurnal Pendidikan Guru Madrasah Ibtidaiah, 3(1), 5361. https://ojs.stitmultazam.ac.id/index.php/JPGMI/article/view/22.

Dewi, W. A. F. (2020). Dampak covid-19 terhadap implementasi pembelajaran daring di sekolah dasar. Edukatif: Jurnal Ilmu Pendidikan, 2(1), 55-61. https://doi.org/10.31004/edukatif.v2i1.89.

Fuadi, R. (2016). Peningkatkan kemampuan pemahaman dan penalaran matematis melalui pendekatan kontekstual. Jurnal Didaktika Matematika, 3(1), 47-54. http://jurnal.unsyiah.ac.id/DM/article/view/4305

Gazali, R. Y. (2016). Pembelajaran matematika yang bermakna. Math Didactic: Jurnal Pendidikan Matematika, 2(3), 181-190.

Hendriana, H., Rohaeti, E. E., \& Sumarmo, U. (2017). Hard skills dan soft skill matematik siswa. Bandung: PT Rafika Aditama.

Hutagaol, K. (2013). Pembelajaran kontekstual untuk meningkatkan kemampuan representasi matematis siswa sekolah menengah pertama. Infinity: Jurnal IImiah Program Studi Matematika STKIP Siliwangi Bandung, 2(1), 85-99. Doi: https://doi.org/10.22460/infinity.v2i1.p85-99.

Kadarisma, G., Sari, I. P., \& Senjayawati, E. (2020). Pengembangan lembar kerja siswa berbasis inkuri untuk meningkatkan hots siswa sma pada materi trigonometri. Teorema: Teori dan Riset Matematika, 5(2), 239-248. Doi: http://dx.doi.org/10.25157/teorema.v5i2.3725.

Kemendikbud. (2020). Surat edaran mendikbud: pelaksanaan kebijakan pendidikan dalam masa darurat penyebaran covid-19. [Online] Diakses: 16 Oktober 2020 Tersedia: https://www.kemdikbud.go.id/main/blog/2020/03/se-mendikbud-pelaksanaan-kebijakanpendidikan-dalam-masa-darurat-penyebaran-covid19

Marwiyah, S., Pujiastuti, H., \& Sukirwan. (2020). Profil kemampuan penalaran matematis siswa ditinjau dari gaya belajar v-a-k pada materi bangun ruang sisi datar. Teorema: Teori dan Riset Matematika, 5(2), 294-307. Doi: http://dx.doi.org/10.25157/teorema.v5i2.3738.

Mulyani, A., Indah, E. K. N., \& Satria, A. P. (2018). Analisis kemampuan pemahaman matematis siswa smp pada materi bentuk aljabar. Mosharafa: Jurnal Pendidikan Matematika, 7(2), 251262. doi: https://doi.org/10.31980/mosharafa.v7i2.24. 
Murtianto, Y. H., Muhtarom., \& Setiyaningrum, E. D. (2019). Pemahaman konsep logaritma siswa sma ditinjau dari kemampuan matematika. Media Penelitian Pendidikan: Jurnal Penelitian dalam Bidang Pendidikan dan Pengajaran, 13(1), 36-41. Doi: http://dx.doi.org/10.26877/mpp.v13i1.5087

National Council of Teachers of Mathematics. (1989). Curriculum and evaluation standards for school mathematics. Reston, Virginia: NCTM. INC.

Nursaadah, I., \& Amelia, R. (2018). Analisis kemampuan pemahaman matematis siswa smp pada materi segitiga dan segiempat. Numeracy Journal, 5(1), 1-9. Doi: https://doi.org/10.46244/numeracy.v5i1.288.

Permendiknas. (2006). Uu no 22 tahun 2006 standar isi untuk satuan pendidikan dasar dan menengah. Jakarta: Depdiknas.

Sari, R. K. (2019). Analisis problematika pembelajaran matematika di sekolah menengah pertama dan solusi alternatifnya. Prismatika: Jurnal Pendidikan dan Riset Matematika, 2(1), 23-31. Doi: https://doi.org/10.33503/prismatika.v2i1.510

Sari, W. P., Suyanto, E., \& Suana, W. (2017). Analisis pemahaman konsep vektor pada siswa sekolah menengah atas. Jurnal Ilmiah Pendidikan Fisika Al-BiRuNi, 6(2), 159-168. Doi: https://doi.org/10.24042/jipfalbiruni.v6i2.1743

Sariningsih, R. (2014). Pendekatan kontekstual untuk meningkatkan kemampuan pemahaman matematis siswa smp. Infinty: Jurnal IImiah Program Studi Matematika STKIP Siliwangi Bandung, 3(2), 150-163. Doi: https://doi.org/10.22460/infinity.v3i2.p150-163

Suprihatin, T. R., Maya, R., \& Senjayawati, E. (2018). Analisis kemampuan penalaran matematis siswa smp pada materi segitiga dan segiempat. JKPM: Jurnal Kajian Pendidikan Matematika, 2(1), 9-13. Doi: https://doi.org/10.22460/infinity.v3i2.p150-163

Susilo, B. E., Darhim., \& Prabawanto, S. (2019). Kesulitan belajar mahasiswa pada materi aplikasi integral untuk luas daerah dalam perspektif disposisi matematis. Kreano: Jurnal Matematika Kreatif-Inovatif, 10(1), 86-93. Doi: http://dx.doi.org/10.15294/kreano.v10i1.19373

Syarifah, L. L. (2017). Analisis kemampuan pemahaman matematis pada mata kuliah pembelajaran matematika sma ii. JPPM: Jurnal Penelitian dan Pembelajaran Matematika, 10(2), 57-71. Doi: http://dx.doi.org/10.30870/jppm.v10i2.2031

Utami, Y. P., \& Cahyono, D. A. D. (2020). Study at home: analisis kesulitan belajar matematika pada proses pembelajaran daring. Jurnal IImiah Matematika Realistik (JI-MR), 1(1), 20-26. Doi: https://doi.org/10.33365/ji-mr.v1i1.252.

Zakiah, N. E. (2020). Level kemampuan metakognitif siswa dalam pembelajaran matematika berdasarkan gaya kognitif. Jurnal Riset Pendidikan Matematika, 7(2), 132-147. Doi: https://doi.org/10.21831/jrpm.v7i2.30458. 